\title{
REVIEW
}

\section{Bench-to-bedside review: Glucose and stress conditions in the intensive care unit}

\author{
Marie-Reine Losser ${ }^{1,2}$, Charles Damoisel ${ }^{1}$ and Didier Payen ${ }^{1 *}$
}

\begin{abstract}
The physiological response to blood glucose elevation is the pancreatic release of insulin, which blocks hepatic glucose production and release, and stimulates glucose uptake and storage in insulin-dependent tissues. When this first regulatory level is overwhelmed (that is, by exogenous glucose supplementation), persistent hyperglycaemia occurs with intricate consequences related to the glucose acting as a metabolic substrate and as an intracellular mediator. It is thus very important to unravel the glucose metabolic pathways that come into play during stress as well as the consequences of these on cellular functions. During acute injuries, activation of serial hormonal and humoral responses inducing hyperglycaemia is called the 'stress response'. Central activation of the nervous system and of the neuroendocrine axes is involved, releasing hormones that in most cases act to worsen the hyperglycaemia. These hormones in turn induce profound modifications of the inflammatory response, such as cytokine and mediator profiles. The hallmarks of stress-induced hyperglycaemia include 'insulin resistance' associated with an increase in hepatic glucose output and insufficient release of insulin with regard to glycaemia. Although both acute and chronic hyperglycaemia may induce deleterious effects on cells and organs, the initial acute endogenous hyperglycaemia appears to be adaptive. This acute hyperglycaemia participates in the maintenance of an adequate inflammatory response and consequently should not be treated aggressively. Hyperglycaemia induced by an exogenous glucose supply may, in turn, amplify the inflammatory response such that it becomes a disproportionate response. Since chronic exposure to glucose metabolites, as encountered in diabetes, induces adverse effects, the proper roles of these metabolites during acute conditions need further elucidation.
\end{abstract}

\section{Introduction}

Acute life-threatening situations cause an intense stress response. These situations promote immuno-inflammatory and metabolic responses that are entangled in an intricate way, as the cells involved in these key events ontogenetically originate from a unique primordial organ combining both immune and metabolic functions, namely the 'fat body' [1]. Acute stress-induced hyperglycaemia [2] is observed in many conditions, such as myocardial infarct [3], and shock states, especially septic [4], but also traumatic [5], as well as stroke [6]. The observed concordance between elevated blood glucose and mortality raised the question of a causative relationship between hyperglycaemia and prognosis [7].

A landmark monocenter study published in 2001 suggested that hyperglycaemia has a deleterious impact

*Correspondence: dpayen1234@orange.fr

'Laboratoire de Recherche Paris 7 (EA 3509), Service d'Anesthésie-Réanimation, Hôpital Lariboisière, Assistance Publique - Hôpitaux de Paris, Université Diderot Paris-7, 75475 Paris Cedex 10, France

Full list of author information is available at the end of the article on prognosis in mostly surgical ICU patients, since tight glucose control by intravenous insulin dramatically improved mortality [8]. The large debate following this publication questioned the population studied (mainly cardiovascular surgical patients), the respective roles of glycaemia control versus additional insulin, and the impact of the amount of exogenous carbohydrate [9]. In 2006, the same group published another study performed on medical ICU patients testing the same protocol used in the first study [10]. In this new study, global mortality did not improve with tight control of glycaemia and a worsening of the death rate in a subgroup of patients staying less than 3 days in the ICU was observed. The group treated with tight control of glycaemia for more than 3 days had a reduction in severity and number of organ failures, which surprisingly did not translate to outcome benefit. Subsequent ICU trials published recently [11-15] have failed to confirm a benefit of tight control of glycaemia on prognosis in critically ill patients while emphasizing the potential role of hypoglycaemia in explaining the divergent results.

The recently published meta-analysis by Marik and Preiser [9] showed that, overall, tight glycaemic control 
did not reduce 28-day mortality (odds ratio (OR) 0.95; $95 \%$ confidence interval (CI), 0.87 to 1.05 ), the incidence of blood stream infections (OR 1.04; 95\% CI, 0.93 to 1.17), or the requirement for renal replacement therapy (OR 1.01; 95\% CI, 0.89 to 1.13 ). The incidence of hypoglycaemia was significantly higher in patients randomized to tight glycaemic control (OR 7.7; 95\% CI, 6.0 to 9.9; $P<0.001)$. Metaregression demonstrated a significant relationship between the 28-day mortality and the proportion of calories provided parenterally $(P=0.005)$, suggesting that the difference in outcome between the two Leuven Intensive Insulin Therapy Trials and the subsequent trials could be related to the use of parenteral nutrition. More importantly, when the two Leuven Intensive Insulin Therapy Trials were excluded from the meta-analysis, mortality was lower in the control patients (OR $0.90 ; 95 \% \mathrm{CI}, 0.81$ to $0.99 ; P=0.04$; $\mathrm{I}(2)=0 \%)$.

The focus of this review is an integrative description of the main pathways and mechanisms involved in the acute stress conditions responsible for hyperglycaemia, and the description of complex situations involving both the stimulation of systemic inflammation and changes in metabolic requirements [16] in an attempt to clarify apparent contradictory results.

\section{Metabolic pathways using glucose during acute critical conditions}

The normal response to a stress situation associates the activation of central nervous system and neuroendocrine axes with increased release of hormones such as cortisol, macrophage inhibiting factor (MIF) $[17,18]$, epinephrine and norepinephrine, growth hormone, and glucagon. These hormones profoundly modify the inflammatory response, especially cytokine release. Stress hormones generate globally a systemic pro-inflammatory profile while anti-inflammation is predominant at the tissue level (for a review, see [19]). These hormones, except for MIF, also stimulate, among other mechanisms, gluconeogenesis and hepatic glucose production, thus aggravating hyperglycaemia [20].

The pancreatic insulin release in response to blood glucose elevation leads to the blocking of hepatic glucose production and the stimulation of glucose uptake and storage by the liver, muscle and adipose tissue. If this first line of regulation fails to control glucose levels, the microenvironment of cells will contain high levels of glucose. To enter the cell, glucose uses transporters that allow facilitated diffusion (via concentration gradients) through the cytoplasmic membrane. These transporters are part of the superfamily of glucose transporters encoded by the GLUT genes; there are several isoforms, such as GLUT4, and their expression on the cell surface is amplified by insulin [21].
After entering the cell, glucose may go through different metabolic pathways in addition to glycolysis, as summarized in Figure 1. During the early hours of stress, the metabolic stimulation of the cell corresponds to increased mitochondrial energy production (ATP) with increased $\mathrm{O}_{2}$ and glucose consumption [22]. Similarly, during cell proliferation, glucose availability is necessary for the induction of glycolytic enzymes, such as hexokinase, pyruvate kinase or lactate dehydrogenase. This glycolysis favours lactate production despite $\mathrm{O}_{2}$ availability [23], and regeneration of $\mathrm{NAD}^{+}$, which is required for additional cycles of glycolysis [24].

\section{Recognition and cellular mechanisms of acute conditions}

Acute critical conditions cause cellular injuries that are known to initiate repair or cell death pathways (Figure 2). These integrative mechanisms tend to either contain the response at the local level or, on the contrary, spread it by recruiting circulating cells and factors for repair.

Damaged cells communicate with innate immune cells by releasing intracellular factors named damage-associated molecular pattern molecules (DAMPs), such as calgranulines [25] and alarmines [26,27] (Figure 2). Together with pathogen-associated molecular pattern molecules (PAMPs), they activate the cellular expression of Toll-like receptors (TLRs) [28]. Accumulation of abnormal proteins, which are processed by the proteasome S26 system in the endoplasmic reticulum [29], as well as fluctuations of nutrients or energy availability, hypoxia, viruses and toxins activate a complex transcriptional response called the endoplasmic reticulum stress response (Figure 2), or the unfolded protein response [30].

Receptors for recognition of inflammation appear on both target cells and inflammatory cells. The alteration of the extracellular milieu is transmitted into the cell, modifying its functions. In peripheral blood mononuclear cells, for instance [31], an increased energy demand associated with a simultaneous metabolic failure can occur $[32,33]$. The increased permeability of the injured mitochondria leads to energy loss and cell death, which by itself fuels the inflammatory process through the release of the cell contents.

\section{Injuries due to cellular environment \\ Hypoxia}

Hypoxia induces hypoxia-inducible factors (HIFs), $\mathrm{O}_{2}-$ sensing transcription factors that regulate the transcription of genes [34] encoding numerous molecules involved in vascular reactivity, recruitment of endothelial progenitors, and cytoprotection [35,36]. During hypoxia (Figure 3), liver and skeletal muscle glycogenolysis is stimulated, increasing glucose availability [37]. Increased expression of GLUTs on any cell type [38-40] is mediated by the activation of AMP kinase and p38 


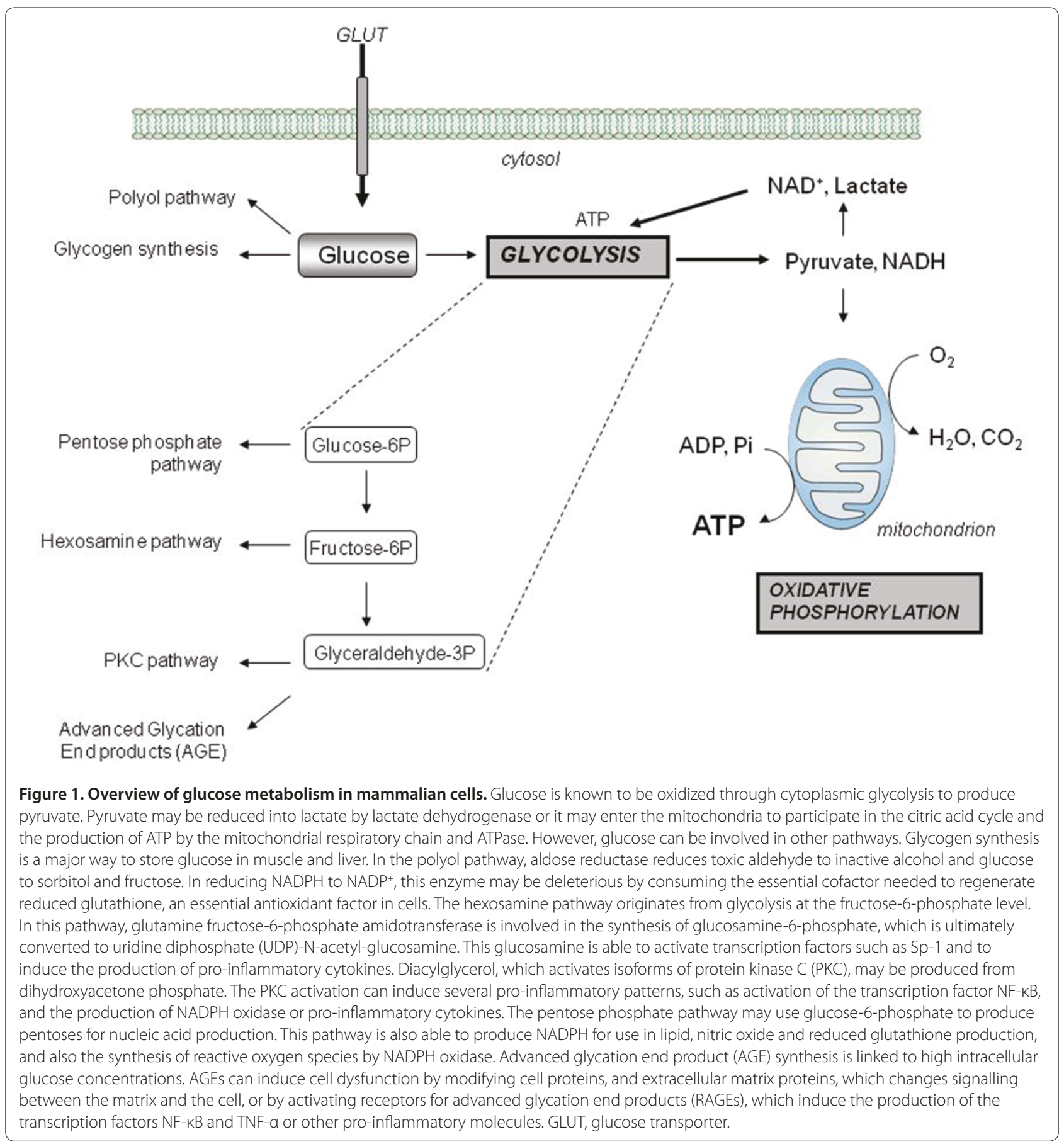

mitogen-activated protein kinase [41,42], with an altered cellular redox status $[41,43]$.

While glycolysis is activated by hypoxia, phosphofructokinase-1 and lactate dehydrogenase activity is stimulated by increased lactate production [44] associated with decreased mitochondrial oxygen consumption. This mechanism, described since 1910 in tumour cells as the 'Warburg effect' [45], seems to be adaptive to the lack of oxygen while maintaining cell redox status. A sufficient amount of energy is then produced but without an increase in reactive oxygen species (ROS) production by the mitochondria [46].

\section{Adenosine}

Adenosine production mainly results from ATP degradation during stress when it is released into the extracellular space. Adenosine regulates innate and adaptive immune functions by interacting with almost every immune cell 


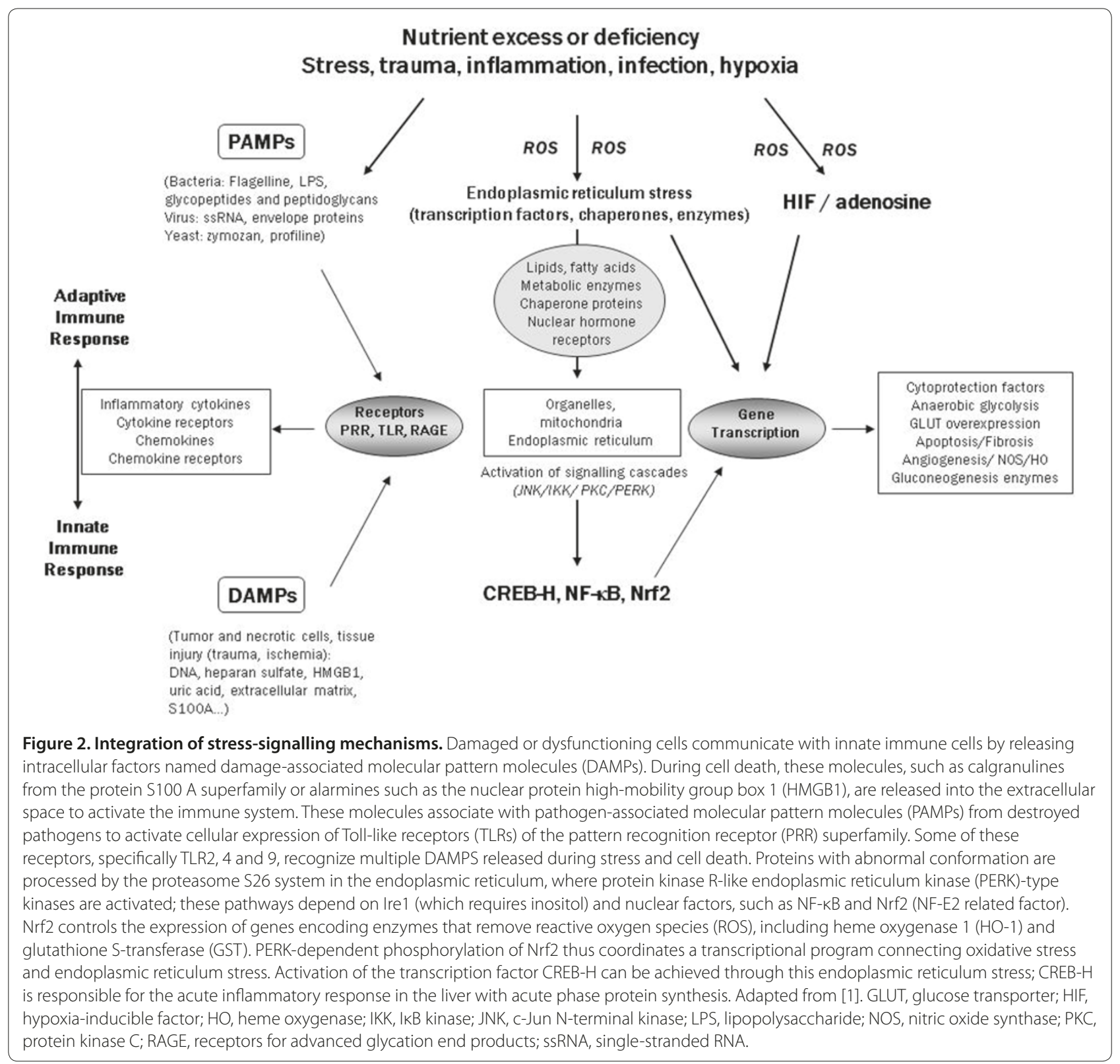

[47]. It inhibits antigen presentation, pro-inflammatory cytokine production and immune cell proliferation, and participates in tissue repair and remodelling. Adenosine induces increased intracellular cAMP, which stimulates protein kinase (PK)A, which in turn activates the transcription factor CREB (cAMP response element-binding), thus linking the inflammatory response to alterations of glucose metabolism [48].

\section{Oxidative stress}

Oxidative stress produces ROS, which alter normal cell function. ROS are permanently released at a low rate at the cytoplasmic membrane (NADPH oxidase, myeloperoxidase, cyclooxygenase) and in the cytoplasm (heme oxygenase, xanthine oxidase), and also within the mitochondria. When activated, phagocytic cells display a specific response called the 'respiratory burst', which is an acute overproduction of ROS by the activation of the NADPH oxidase Nox 2. Oxidative stress may indirectly modify glucose metabolism since it induces DNA alterations that activate the nuclear enzyme poly-ADP-ribose polymerase 1 (PARP-1). This activation consumes NAD ${ }^{+}$ and depletes its intracellular stores, which in turn hampers glycolysis and ATP production, in parallel with altered cell functions [49]. A transient low level of oxidative stress with redox alterations stimulates glucose uptake via insulin-independent GLUT transporters mediated by the AMP kinase pathway $[50,51]$. 


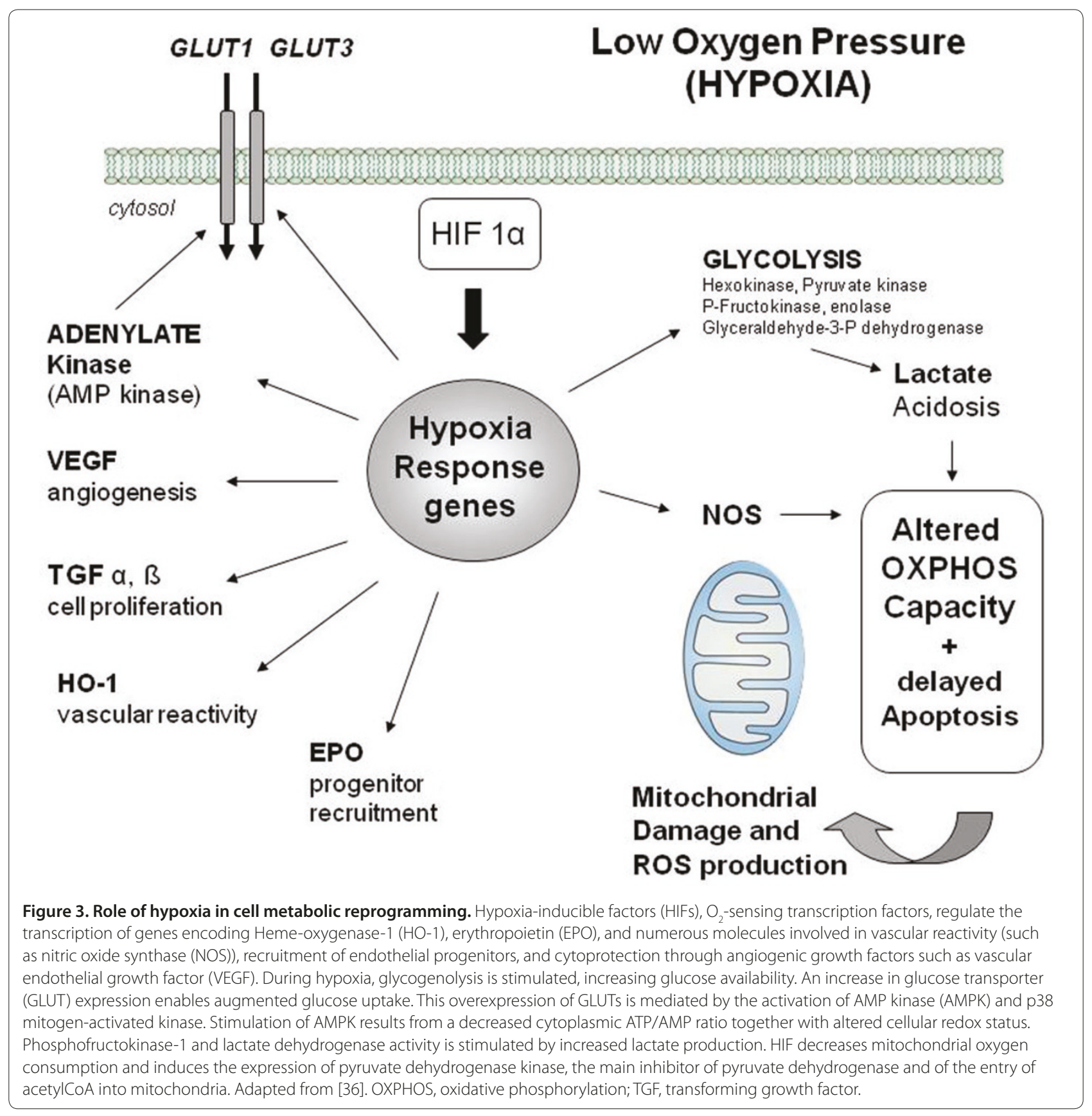

\section{Sepsis, an integrative condition}

Sepsis corresponds to a systemic inflammation related to the abnormal presence of bacterial antigens and involves different mechanisms such as hypoxia and oxidative stress. At the early phase, inhibition of glycogen synthesis results in increased global glucose availability and increased cellular uptake [52-54]. Glucose uptake appears to be most increased in organs containing a vast population of phagocytic cells (liver, spleen, gut, lung) [55-57]. In rats injected with endotoxin or TNF- $\alpha$, insulin-independent glucose uptake is increased in liver non-parenchymal cells (Küpffer cells, endothelial cells) [58], as observed in circulating immune cells, including polymorphonuclear leukocytes [59,60], lymphocytes, monocytes and macrophages [61-63]. Skeletal muscle displays only a limited increase in glucose uptake, probably because of the development of insulin resistance.

Sepsis also modifies cytoplasmic glycolysis at the transcriptional level. In healthy volunteers receiving intravenous endotoxin, there was an early under-expression of genes encoding metabolic enzymes [64]. In particular, the key enzymes of glycolysis and those of the 
mitochondrial respiratory chain (MRC) were transiently under-expressed. In the diaphragm of septic rats, transcription, synthesis and activity of the constituents of the MRC, as well as of phosphofructokinase-1, a keyenzyme of glycolysis, are reduced [65]. In muscle of septic rats, the activity of pyruvate dehydrogenase is reduced, with a simultaneous increase in the activity of its inhibitor, pyruvate dehydrogenase kinase. The net result of these modifications is a reduction in pyruvate entering the mitochondria while the conversion of pyruvate to lactate is promoted [66].

In septic shock patients, increased use of glucose and increased lactate production was observed under aerobic conditions [67]. A microdialysis study of quadriceps muscles showed lactate overproduction during septic shock resulting form exaggerated aerobic glycolysis through $\mathrm{Na} / \mathrm{K}$-ATPase stimulation. To maintain cell functions, stimulation of glycolysis was shown to adaptively compensate for the metabolic rate increase [68]. Elevated circulating epinephrine stimulates $\mathrm{Na} / \mathrm{K}$-ATPase, which promotes lactate hyperproduction without any oxygen debt [69].

Mitochondrial dysfunction during sepsis [70] involves alterations in the structure [71] and function of the MRC, including impairment of key enzymes of electron transport and ATP synthesis [72,73] and mitochondrial biogenesis [74]. These results were also found with monocytes [75] and skeletal muscle [76] harvested from septic shock patients. ATP levels in skeletal muscle cells were maintained despite mitochondrial ultrastructural alterations [76]. This mitochondrial dysfunction results from plasmatic factors that promote uncoupled MRC oxygen consumption [77] that correlates with sepsisinduced modifications of the immune phenotype and is associated with increased mitochondrial permeability [78].

In summary, glucose metabolism alterations in acute critical conditions can be viewed as a 'redistribution of glucose consumption away from mitochondrial oxidative phosphorylation' towards other metabolic pathways, such as lactate production. This re-channelling does not seem to affect energy supply to the cells. This may result from decreased ATP consumption by the cells, which in turn lose some of their characteristics, indicating metabolic failure [79].

\section{Why does glycaemia finally increase during acute injury?}

Stress-induced hyperglycaemia results from the combined effects of increased counter-regulatory hormones that stimulate glucose production and reduced uptake associated with insulin resistance, that is, decreased insulin activity. There is also inadequate pancreatic insulin release with regard to glycaemia (or adaptive 'pancreas tolerance'). Insulin release during stress is decreased mainly through the stimulation of $\alpha$-adrenergic pancreatic receptors [20]. Pro-inflammatory cytokines may directly inhibit insulin release by $\beta$ pancreatic cells [80]. A new glucose balance results, allowing a higher blood 'glucose pressure', which affects tissues differently depending on whether they are insulin-dependent or not.

Glucose availability also relies on delivery to cells, analogous to oxygen diffusion. For glucose to arrive at a cell with reduced blood flow (ischemia, sepsis), it must move from the blood stream across the interstitial space. Glucose movement is dependent entirely on a concentration gradient, and for adequate delivery to occur across an increased distance, the concentration at the origin (blood) must be greater. Therefore, in the face of reduced or redistributed blood flow, hyperglycaemia is adaptive.

\section{Development of insulin resistance}

Insulin resistance (IR) is a reduction in the direct effect of insulin on its signalling process leading to metabolic consequences [81], very similar to type 2 diabetes, and is commonly observed during sepsis [82].

Insulin acts mainly on the liver, muscle and fat (metabolic effects), but it also targets many cellular subtypes to stimulate essentially protein and DNA synthesis as well as apoptosis (mitogenic effects). Hepatic IR involves increased hepatic glucose production (gluconeogenesis) together with decreased glycogen synthesis. During sepsis, however, gluconeogenesis can be limited by inhibition of important enzymes [83,84]. Muscle IR corresponds to decreased glycogen deposition and glucose uptake linked to decreased expression of GLUT4, while a transient defect in insulin signalling has also been described [85]. IR in adipocytes leads to inhibition of lipogenesis and activation of lipolysis.

\section{The main mediators}

Pro-inflammatory cytokines (IL-6, TNF- $\alpha$ ), as well as endotoxins via TLR4, participate in the development of IR by stimulating hepatic glucose production [86] and altering insulin signalling [87]. These cytokines activate numerous kinases that inhibit insulin signal transduction [88-91]. TNF- $\alpha$ has been shown to induce the expression of SOCS-3 (Suppressor of cytokine signalling-3), which specifically inhibits insulin receptor phosphorylation [92].

MIF is not only produced by various immune cells [93] and the anterior pituitary gland, but also by islet $\beta$ cells, where it positively regulates insulin secretion [94]. During inflammation in skeletal muscle, locally produced MIF stimulates glucose use and lactate production [95]. In endotoxemic mice genetically deficient in MIF, glucose metabolism is almost normalized when compared to wild-type mice [96]. Increased circulating cortisol participates in the maintenance of blood glucose not only by 
increasing its production or decreasing its utilization, but also by directly inhibiting insulin secretion by $ß$ cells [97].

Endogenous catecholamines are also involved in the alteration of glucose metabolism during endotoxaemia [98], especially in the liver [99]. Exogenous epinephrine metabolic effects on glucose turnover were, however, attenuated in endotoxic rats when compared to controls [100].

\section{Role of exogenous glucose supply and induced hyperglycaemia}

Glucose acts not only as an energetic substrate but also as a signalling molecule of the cellular environment, as shown in diabetes with chronic hyperglycaemia. Stressinduced acute hyperglycaemia has been less studied up to now as it has been considered an adaptive response. Some concepts from chronic hyperglycaemia may, however, be used in acute conditions. Intravenous administration of exogenous glucose yielded similar glycaemia in control and septic animals despite higher insulin levels in the septic group [101]. Hepatic glycogen deposition was observed only when glucose was infused via the portal vein $[31,102]$.

\section{Glucose-controlled genomic modifications}

In fasted animals, increased circulating glucagon induces a gluconeogenic program by activating the nuclear transription factor CREB through a molecule named Crtc2 (CREB regulated transcription coactivator 2) or TORC 2 (Transducer of regulated CREB activity 2) [103,104]. The expression rate of gluconeogenic enzymes is thus increased, especially for glucose-6-phosphatase.

Re-feeding in turn increases insulin levels, which inhibits hepatic glucose production partly by ubiquitindependent destruction of Crtc2 [105]. During sustained hyperglycaemia, the hexosamine pathway can be activated [106]. In hepatocytes, Crtc2 is then O-glycosylated on a serine residue instead of being phosphorylated. It can thus migrate into the nucleus to activate CREB and the gluconeogenic program, contributing to maintain hyperglycaemia [107]. This has been described as the 'sweet conundrum' [105]. Regulation of this pathway during acute injury remains to be proven.

\section{Hyperglycaemia and the inflammatory response}

In diabetics, glucose channelling through alternative glycolytic pathways seems to depend on MRC activity $[106,108]$. The accumulation of energy substrates induced by isolated hyperglycaemia without a concomitant increase in energy demand may enhance the flux of carbon hydrates to the mitochondria with increased activity of the MRC and proton driving force. Once the activity of ATPase is saturated, intermediate radicals from the MRC will accumulate and may react with the surrounding available $\mathrm{O}_{2}$ to produce ROS [109], as shown in bovine endothelial cells. When inhibiting this radical production, the activity of alternative glycolytic pathways is decreased as well as the expression of transcription factor NF-kB [110]. Inhibition of glyceraldehyde-3-phosphate dehydrogenase, an enzyme involved in cytoplasmic glycolysis, has also been observed. Metabolites accumulate upstream of this enzyme and are funnelled towards alternative pathways (Figure 1). Polymers of ADP-ribose, produced by nuclear PARP to repair DNA altered by mitochondrial ROS, may be involved in this inhibition. PARP, by migrating into the cytosol, may be a key to glucose toxicity [111]. There is still a lack of evidence to fully extrapolate these theories to explain mitochondrial dysfunction and organ failure observed during stressinduced hyperglycaemia.

Glucose also acts as a pro-inflammatory molecule $[81,112]$. Glucose ingestion in healthy volunteers rapidly increases the activity of NF- $\mathrm{KB}$ [113] and the production of mRNA for TNF- $\alpha$ [114]. Under the same conditions, acute hyperglycaemia increased the activity of the transcription factors AP-1 (Activator protein-1) and EGR-1 (Early growth response-1), which in turn activate the production of matrix metalloproteinase-2 (MMP-2) by monocytes, an enzyme that facilitates the diffusion of inflammation by hydrolysing extracellular matrix. Production of tissue factor, a prothrombotic and proaggregant molecule [115], is increased, as is production of cellular adhesion molecules [116]. Acute hyperglycaemia induced in healthy volunteers by octreotid, an inhibitor of insulin release, leads to a rapid and transient secretion of proinflammatory cytokines (IL-6, TNF $\alpha$, IL-8). This effect is amplified in insulin-resistant subjects and blunted with antiradical treatment [117].

\section{Glucose-cytokine interactions}

In vitro, an increased release of IL-1ß has been measured in the culture medium of human monocytes exposed to hyperglycaemic conditions after endotoxin stimulation [118]. In our model of endotoxaemia [102], glucose supply interfered with haemodynamic, metabolic and inflammatory responses, with a dramatic increase in circulating TNF- $\alpha$ when intraportal glucose was administered. Fasting on the other hand seemed to attenuate the response to endotoxin.

In liver transplant patients, glucose feeding during the early postoperative period induced major haemodynamic modifications within the graft, where the immunoinflammatory insult occurs [119], including almost halted arterial hepatic inflow. This vasoconstriction was specifically related to glucose since fructose, amino acids and fatty acids did not provoke this effect. One tempting hypothesis for this effect involves increased production of ROS, which are well known to vasoconstrict arteries. 


\section{Glucose and ROS production}

Nutrients, and especially glucose, are able to stimulate oxidative stress and inflammatory responses [106]. The body thus needs to regulate nutrient excesses in order to maintain metabolic homeostasis. STAMP2 (Six-transmembrane protein of prostate 2) has recently been detected in adipose tissue, a key organ in the management of nutrient excesses, and is also expressed in the heart, liver, lung and platelets [120]. In STAMP2 genetically deficient mice, the effects of insulin on liver, muscle and adipose tissue are altered, all three being essential organs for glucose homeostasis. STAMP2 is a metalloreductase involved in iron handling, which may influence ROS production [121]. Ingestion of glucose in healthy volunteers led to increased production of ROS in circulating monocytes and polymorphonuclear leukocytes. This was associated with the rapidly increased synthesis of NADPH oxidase subunits [122].

These data suggest that glucose induces profound modifications of the monocyte pro-inflammatory response. In peripheral blood mononuclear cells harvested from healthy volunteers and septic patients [77,123], increasing extracellular glucose increased glucose uptake. Subsequent stimulation of these cells by various agonists increased ROS production via NADPH oxidase in both the healthy volunteers and the septic patients. The link between ROS and intracellular glucose levels could be the increased production of NADPH via the pentose phosphate cycle [123] (Figure 4). More studies are needed to confirm these multifaceted effects and to confirm that such a coordinated regulation between nutrient availability and the intensity of the inflammatory response is also at play during acute insults. To cite Leverve, 'it appears that glucose obviously plays a very subtle role in oxidant cellular signaling. It can either increase or decrease ROS production and can either increase or decrease the antioxidant defense [...]. Therefore it is not surprising that any change in blood glucose must be considered as a complex event, and taking care of glycemia and redox homeostasis will be probably central in the management of ICU patients in the next years' [124].

Recent in vitro data suggest that giving glucose boluses after hypoglycaemia may trigger neuronal death due to ROS overproduction [125]. In healthy volunteers, hyperglycaemic spikes induced increased pro-inflammatory cytokine levels that were blunted by antioxidant pretreatment [117]. This introduces the concept of glucose variability, which by itself seems to be deleterious with regard to outcome in critically ill patients $[126,127]$.

\section{Future prospects}

Many questions regarding glycaemia remain to be solved for daily critical care practice. How should we achieve glycaemic control: should we take into account

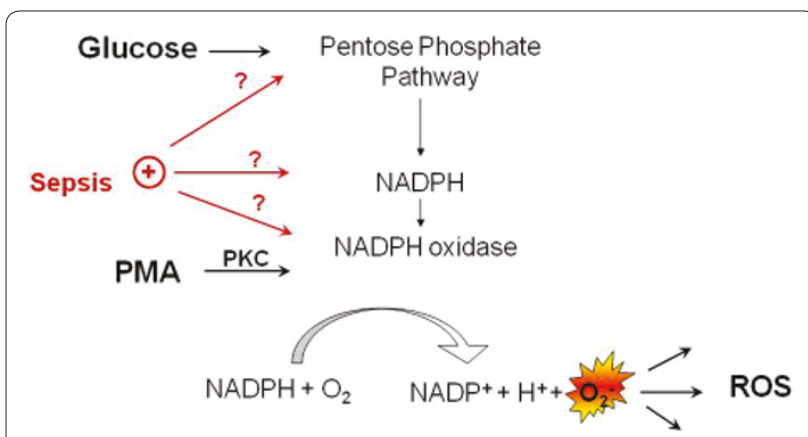

Figure 4. Glucose and reactive oxygen species production during sepsis: hypothesis. In peripheral blood mononuclear cells harvested from healthy volunteers and septic patients, increasing extracellular glucose increased glucose uptake. Subsequent stimulation of these cells by various agonists, such as PMA (phorbol 12-myristate 13-acetate), a protein kinase C (PKC) activator, increased reactive oxygen species (ROS) production via NADPH oxidase in both the healthy volunteers and septic patients. The link between ROS and intracellular glucose levels could be increased production of $\mathrm{NADPH}$ via the pentose phosphate pathway.

nutritional support, especially parenteral nutrition [9]? Should we control the physiological response to an induced hyperglycaemia or should we control the endogenous stress-induced hyperglycaemia that may be adaptive in the absence of exogenous glucose intake? Is there a place for new therapeutics such as incretins [128]? Does endogenous hyperglycaemia have a similar impact as hyperglycaemia induced by nutritional support? These questions in turn prompt investigation of the role of glucose deprivation induced by fasting with regard to normoglycemia achieved by insulin therapy. Similarly, the consequences of spontaneous versus insulin-induced hypoglycaemia remain to be investigated. Answers to these questions will probably help to solve the conflict between supporters and opponents of tight glycaemia control in the ICU. This discussion is in accordance with the concerns raised by several authors about early initiation of parenteral nutrition in acute critical patients $[129,130]$, as supported by the results of two large multicentre studies, Nice-Sugar [14] and Glucontrol [15].

\section{Conclusion}

Glucose metabolism is profoundly altered during acute conditions, from its uptake to the induction of complex programs of gene expression [14]. The increased glucose availability in cells is not necessarily used to produce ATP by mitochondria. Glucose seems able to activate proinflammatory metabolic pathways. While chronic exposure to these end products seems deleterious (diabetes), their actual roles during acute conditions need to be further elucidated. Early stress-induced hyperglycaemia has been described as an adaptive response that could in turn sustain an adaptive inflammatory response (host 
defence, wound healing, and so on). Glucose intakeinduced hyperglycaemia may, however, lead to maladjusted and disproportionate inflammation that should be avoided. How then should this subsequent hyperglycaemia be prevented: should we limit glucose supply at the early phase of inflammation?

\section{Si quis febricitanti cibum det, convalescenti quidem, robur : agrotanti verò, morbus fit}

Hippocrates [131]

(Food given to those who are convalescent from fever, increases strength; but if there be still disease, increases the disease)

\section{Abbreviations}

$\mathrm{Cl}=$ confidence interval; $\mathrm{CREB}=\mathrm{CAMP}$ response element-binding; $\mathrm{CrtC}=$ CREB regulated transcription coactivator; GLUT = glucose transporter; HIF = hypoxia-inducible factor; $I L=$ interleukin; $I R=$ insulin resistance; $M I F=$ macrophage inhibiting factor; $\mathrm{MRC}=$ mitochondrial respiratory chain; $\mathrm{NF}-\mathrm{KB}=$ nuclear factor kappa-light-chain-enhancer of activated $\mathrm{B}$ cells; $\mathrm{OR}=$ odds ratio; PARP-1 = poly-ADP-ribose polymerase $1 ; \mathrm{PK}=$ protein kinase; $\mathrm{ROS}=$ reactive oxygen species; TLR = toll-like receptor; TNF = tumour necrosis factor.

\section{Competing interests}

The authors declare that they have no competing interests.

\section{Authors' contributions}

$M R L, C D$, and DP participated in the analysis of references and writing of this review.

\section{Acknowledgements}

This work was partially supported by grant'Plan Quadriennal Ministère de la Recherche' 2009-2013.

\section{Author details}

'Laboratoire de Recherche Paris 7 (EA 3509), Service d'AnesthésieRéanimation, Hôpital Lariboisière, Assistance Publique - Hôpitaux de Paris, Université Diderot Paris-7, 75475 Paris Cedex 10, France. ${ }^{2}$ Service d'AnesthésieRéanimation, Hôpital Saint-Louis, Assistance Publique - Hôpitaux de Paris, Université Diderot Paris-7, 75475 Paris Cedex 10, France.

Published: 20 August 2010

\section{References}

1. Hotamisligil GS: Inflammation and metabolic disorders. Nature 2006 , 444:860-867.

2. Bernard C: Leçon sur les Phénomènes de la Vie Communs aux Animaux et aux Végétaux. Paris, France: JB Baillière et Fils; 1877.

3. Capes SE, Hunt D, Malmberg K, Gerstein HC: Stress hyperglycaemia and increased risk of death after myocardial infarction in patients with and without diabetes: a systematic overview. Lancet 2000, 355:773-778.

4. Van den Berghe G: Molecular biology: a timely tool for further unraveling the "diabetes of stress". Crit Care Med 2001, 29:910-911.

5. Laird AM, Miller PR, Kilgo PD, Meredith JW, Chang MC: Relationship of early hyperglycemia to mortality in trauma patients. J Trauma 2004, 56:1058-1062

6. Capes SE, Hunt D, Malmberg K, Pathak P, Gerstein HC: Stress hyperglycemia and prognosis of stroke in nondiabetic and diabetic patients: a systematic overview. Stroke 2001, 32:2426-2432.

7. Mizock BA: Alterations in carbohydrate metabolism during stress: a review of the literature. Am J Med 1995, 98:75-84.

8. Van den Berghe $G$, Wouters P, Weekers F, Verwaest C, Bruyninckx F, Schetz M, Vlasselaers D, Ferdinande P, Lauwers P, Bouillon R: Intensive insulin therapy in the critically ill patients. N Engl J Med 2001, 345:1359-1367.

9. Marik PE, Preiser JC: Toward understanding tight glycemic control in the ICU: a systematic review and metaanalysis. Chest 2010, 137:544-551.
10. Van den Berghe G, Wilmer A, Hermans G, Meersseman W, Wouters PJ, Milants I, Van Wijngaerden E, Bobbaers H, Bouillon R: Intensive insulin therapy in the medical ICU. N Engl J Med 2006, 354:449-461.

11. Brunkhorst FM, Engel C, Bloos F, Meier-Hellmann A, Ragaller M, Weiler N, Moerer O, Gruendling M, Oppert M, Grond S, Olthoff D, Jaschinski U, John S, Rossaint R, Welte T, Schaefer M, Kern P, Kuhnt E, Kiehntopf M, Hartog C, Natanson C, Loeffler M, Reinhart K: Intensive insulin therapy and pentastarch resuscitation in severe sepsis. N Engl J Med 2008, 358:125-139.

12. De La Rosa Gdel C, Donado JH, Restrepo AH, Quintero AM, Gonzalez LG, Saldarriaga NE, Bedoya M, Toro JM, Velasquez JB, Valencia JC, Arango CM, Aleman PH, Vasquez EM, Chavarriaga JC, Yepes A, Pulido W, Cadavid CA: Strict glycaemic control in patients hospitalised in a mixed medical and surgical intensive care unit: a randomised clinical trial. Crit Care 2008, 12:R120.

13. Arabi YM, Dabbagh OC, Tamim HM, Al-Shimemeri AA, Memish ZA, Haddad SH, Syed SJ, Giridhar HR, Rishu AH, Al-Daker MO, Kahoul SH, Britts RJ, Sakkijha $\mathrm{MH}$ : Intensive versus conventional insulin therapy: a randomized controlled trial in medical and surgical critically ill patients. Crit Care Med 2008, 36:3190-3197.

14. Finfer $S$, Chittock DR, Su SY, Blair D, Foster D, Dhingra V, Bellomo R, Cook D, Dodek P, Henderson WR, Hebert PC, Heritier S, Heyland DK, McArthur C, McDonald E, Mitchell I, Myburgh JA, Norton R, Potter J, Robinson BG, Ronco $\mathrm{JJ}$ : Intensive versus conventional glucose control in critically ill patients. N Engl J Med 2009, 360:1283-1297.

15. Preiser JC, Devos P, Ruiz-Santana S, Melot C, Annane D, Groeneveld J, lapichino G, Leverve X, Nitenberg G, Singer P, Wernerman J, Joannidis M, Stecher A, Chiolero R: A prospective randomised multi-centre controlled trial on tight glucose control by intensive insulin therapy in adult intensive care units: the Glucontrol study. Intensive Care Med 2009, 35:1738-1748.

16. Dandona P, Chaudhuri A, Ghanim H, Mohanty P: Anti-inflammatory effects of insulin and the pro-inflammatory effects of glucose. Semin Thorac Cardiovasc Surg 2006, 18:293-301.

17. Calandra T, Echtenacher B, Roy DL, Pugin J, Metz CN, Hultner L, Heumann D, Mannel D, Bucala R, Glauser MP: Protection from septic shock by neutralization of macrophage migration inhibitory factor. Nat Med 2000, 6:164-170.

18. Calandra T, Roger T: Macrophage migration inhibitory factor: a regulator of innate immunity. Nat Rev Immunol 2003, 3:791-800.

19. Calcagni E, Elenkov I: Stress system activity, innate and T helper cytokines, and susceptibility to immune-related diseases. Ann N Y Acad Sci 2006, 1069:62-76.

20. Mizock BA: Alterations in fuel metabolism in critical illness: hyperglycaemia. Best Pract Res Clin Endocrinol Metab 2001, 15:533-551.

21. Shepherd PR, Kahn BB: Glucose transporters and insulin action implications for insulin resistance and diabetes mellitus. N Engl J Med 1999, 341:248-257.

22. Singer M, Brealey D: Mitochondrial dysfunction in sepsis. Biochem Soc Symp 1999, 66:149-166.

23. Greiner EF, Guppy M, Brand K: Glucose is essential for proliferation and the glycolytic enzyme induction that provokes a transition to glycolytic energy production. J Bio/ Chem 1994, 269:31484-31490.

24. Denko NC: Hypoxia, HIF1 and glucose metabolism in the solid tumour. Nat Rev Cancer 2008, 8:705-713.

25. Heizmann CW, Ackermann GE, Galichet A: Pathologies involving the $\mathrm{S} 100$ proteins and RAGE. Subcell Biochem 2007, 45:93-138.

26. Bianchi ME, Manfredi AA: High-mobility group box 1 (HMGB1) protein at the crossroads between innate and adaptive immunity. Immunol Rev 2007 220:35-46.

27. Klune JR, Dhupar R, Cardinal J, Billiar TR, Tsung A: HMGB1: endogenous danger signaling. Mol Med 2008, 14:476-484.

28. Barton GM: A calculated response: control of inflammation by the innate immune system. J Clin Invest 2008, 118:413-420.

29. Marciniak SJ, Ron D: Endoplasmic reticulum stress signaling in disease. Physiol Rev 2006, 86:1133-1149.

30. Schroder M, Kaufman RJ: The mammalian unfolded protein response. Annu Rev Biochem 2005, 74:739-789.

31. Adkins BA, Myers SR, Hendrick G, Stevenson RW, Williams PE, Cherrington AD: Importance of the route of intravenous glucose delivery to hepatic glucose balance in the conscious dog. J Clin Invest 1987, 79:557-565.

32. Crouser E, Exline M, Knoell D, Wewers MD: Sepsis: links between pathogen sensing and organ damage. Curr Pharm Des 2008, 14:1840-1852. 
33. Carre JE, Singer M: Cellular energetic metabolism in sepsis: the need for a systems approach. Biochim Biophys Acta 2008, 1777:763-771.

34. Safran M, Kaelin WG Jr: HIF hydroxylation and the mammalian oxygensensing pathway. J Clin Invest 2003, 111:779-783.

35. Legrand M, Mik EG, Johannes T, Payen D, Ince C: Renal hypoxia and dysoxia after reperfusion of the ischemic kidney. Mol Med 2008, 14:502-516.

36. Bellance N, Lestienne P, Rossignol R: Mitochondria: from bioenergetics to the metabolic regulation of carcinogenesis. Front Biosci 2009, 14:4015-4034.

37. Wu Y, Wang H, Brautigan DL, Liu Z: Activation of glycogen synthase in myocardium induced by intermittent hypoxia is much lower in fasted than in fed rats. Am J Physiol Endocrinol Metab 2007, 292:E469-475.

38. Bruckner BA, Ammini CV, Otal MP, Raizada MK, Stacpoole PW: Regulation of brain glucose transporters by glucose and oxygen deprivation. Metabolism 1999, 48:422-431.

39. Cartee GD, Douen AG, Ramlal T, Klip A, Holloszy JO: Stimulation of glucose transport in skeletal muscle by hypoxia. J Appl Physiol 1991, 70:1593-1600.

40. Burke B, Giannoudis A, Corke KP, Gill D, Wells M, Ziegler-Heitbrock L, Lewis CE: Hypoxia-induced gene expression in human macrophages: implications for ischemic tissues and hypoxia-regulated gene therapy. Am J Pathol 2003, 163:1233-1243.

41. Pelletier A, Joly E, Prentki M, Coderre L: Adenosine 5'-monophosphateactivated protein kinase and p38 mitogen-activated protein kinase participate in the stimulation of glucose uptake by dinitrophenol in adult cardiomyocytes. Endocrinology 2005, 146:2285-2294.

42. Barnes $K$, Ingram JC, Porras OH, Barros LF, Hudson ER, Fryer LG, Foufelle F, Carling D, Hardie DG, Baldwin SA: Activation of GLUT1 by metabolic and osmotic stress: potential involvement of AMP-activated protein kinase (AMPK). J Cell Sci 2002, 115:2433-2442

43. Corton JM, Gillespie JG, Hardie DG: Role of the AMP-activated protein kinase in the cellular stress response. Curr Biol 1994, 4:315-324.

44. Hwang DY, Ismail-Beigi F: Glucose uptake and lactate production in cells exposed to $\mathrm{CoCl}(2)$ and in cells overexpressing the Glut-1 glucose transporter. Arch Biochem Biophys 2002, 399:206-211.

45. Brahimi-Horn MC, Chiche J, Pouyssegur J: Hypoxia signalling controls metabolic demand. Curr Opin Cell Biol 2007, 19:223-229.

46. Kim JW, Tchernyshyov I, Semenza GL, Dang CV: HIF-1-mediated expression of pyruvate dehydrogenase kinase: a metabolic switch required for cellular adaptation to hypoxia. Cell Metab 2006, 3:177-185.

47. Hasko G, Cronstein BN: Adenosine: an endogenous regulator of innate immunity. Trends Immunol 2004, 25:33-39.

48. Hasko G, Pacher P: A2A receptors in inflammation and injury: lessons learned from transgenic animals. J Leukoc Biol 2008, 83:447-455.

49. Pacher P, Szabo C: Role of poly(ADP-ribose) polymerase 1 (PARP-1) in cardiovascular diseases: the therapeutic potential of PARP inhibitors. Cardiovasc Drug Rev 2007, 25:235-260

50. Katz A: Modulation of glucose transport in skeletal muscle by reactive oxygen species. J Appl Physio/ 2007, 102:1671-1676.

51. Horie T, Ono K, Nagao K, Nishi H, Kinoshita M, Kawamura T, Wada H, Shimatsu A, Kita T, Hasegawa K: Oxidative stress induces GLUT4 translocation by activation of PI3-K/Akt and dual AMPK kinase in cardiac myocytes. J Cell Physiol 2008, 215:733-742.

52. Wallington J, Ning J, Titheradge MA: The control of hepatic glycogen metabolism in an in vitro model of sepsis. Mol Cell Biochem 2008, 308:183-192.

53. Agwunobi AO, Reid C, Maycock P, Little RA, Carlson GL: Insulin resistance and substrate utilization in human endotoxemia. J Clin Endocrinol Metab 2000, 85:3770-3778

54. Saeed M, Carlson GL, Little RA, Irving MH: Selective impairment of glucose storage in human sepsis. Br J Surg 1999, 86:813-821.

55. Meszaros K, Lang CH, Bagby GJ, Spitzer JJ: Contribution of different organs to increased glucose consumption after endotoxin administration. J Biol Chem 1987, 262:10965-10970.

56. Meszaros K, Lang CH, Bagby GJ, Spitzer JJ: In vivo glucose utilization by individual tissues during non-lethal hypermetabolic sepsis. FASEB J 1988 2:3083-3086.

57. Meszaros K, Bojta J, Bautista AP, Lang CH, Spitzer JJ: Glucose utilization by Kupffer cells, endothelial cells, and granulocytes in endotoxemic rat liver Am J Physiol 1991, 260:G7-G12.

58. Spolarics Z, Schuler A, Bagby GJ, Lang CH, Meszaros K, Spitzer JJ: Tumor necrosis factor increases in vivo glucose uptake in hepatic nonparenchymal cells. J Leukoc Biol 1991, 49:309-312.
59. Schuster DP, Brody SL, Zhou Z, Bernstein M, Arch R, Link D, Mueckler M: Regulation of lipopolysaccharide-induced increases in neutrophil glucose uptake. Am J Physiol Lung Cell Mol Physiol 2007, 292:L845-851.

60. Battelino T, Goto M, Krzisnik C, Zeller WP: Tumor necrosis factor-alpha alters glucose metabolism in suckling rats. J Lab Clin Med 1999, 133:583-589.

61. Fu Y, Maianu L, Melbert BR, Garvey WT: Facilitative glucose transporter gene expression in human lymphocytes, monocytes, and macrophages: a role for GLUT isoforms 1, 3, and 5 in the immune response and foam cell formation. Blood Cells Mol Dis 2004, 32:182-190.

62. Malide D, Davies-Hill TM, Levine M, Simpson IA: Distinct localization of GLUT-1, -3, and -5 in human monocyte-derived macrophages: effects of cell activation. Am J Physiol 1998, 274:E516-526.

63. Gamelli RL, Liu H, He LK, Hofmann CA: Augmentations of glucose uptake and glucose transporter-1 in macrophages following thermal injury and sepsis in mice. J Leukoc Biol 1996, 59:639-647.

64. Calvano SE, Xiao W, Richards DR, Felciano RM, Baker HV, Cho RJ, Chen RO, Brownstein BH, Cobb JP, Tschoeke SK, Miller-Graziano C, Moldawer LL, Mindrinos MN, Davis RW, Tompkins RG, Lowry SF: A network-based analysis of systemic inflammation in humans. Nature 2005, 437:1032-1037.

65. Callahan LA, Supinski GS: Downregulation of diaphragm electron transport chain and glycolytic enzyme gene expression in sepsis. J Appl Physiol 2005, 99:1120-1126.

66. Vary TC: Sepsis-induced alterations in pyruvate dehydrogenase complex activity in rat skeletal muscle: effects on plasma lactate. Shock 1996 6:89-94.

67. Gore DC, Jahoor F, Hibbert JM, DeMaria EJ: Lactic acidosis during sepsis is related to increased pyruvate production, not deficits in tissue oxygen availability. Ann Surg 1996, 224:97-102.

68. Levy B, Gibot S, Franck P, Cravoisy A, Bollaert PE: Relation between muscle $\mathrm{Na}+\mathrm{K}+$ ATPase activity and raised lactate concentrations in septic shock: a prospective study. Lancet 2005, 365:871-875.

69. James JH, Luchette FA, McCarter FD, Fischer JE: Lactate is an unreliable indicator of tissue hypoxia in injury or sepsis. Lancet 1999, 354:505-508.

70. Fink MP: Bench-to-bedside review: Cytopathic hypoxia. Crit Care 2002, 6:491-499.

71. Crouser ED, Julian MW, Blaho DV, Pfeiffer DR: Endotoxin-induced mitochondrial damage correlates with impaired respiratory activity. Crit Care Med 2002, 30:276-284.

72. Levy RJ: Mitochondrial dysfunction, bioenergetic impairment, and metabolic down-regulation in sepsis. Shock 2007, 28:24-28.

73. Levy RJ, Deutschman CS: Cytochrome c oxidase dysfunction in sepsis. Crit Care Med 2007, 35(9 Suppl):S468-475.

74. Haden DW, Suliman HB, Carraway MS, Welty-Wolf KE, Ali AS, Shitara H, Yonekawa H, Piantadosi CA: Mitochondrial biogenesis restores oxidative metabolism during Staphylococcus aureus sepsis. Am J Respir Crit Care Med 2007, 176:768-777

75. Adrie C, Bachelet M, Vayssier-Taussat M, Russo-Marie F, Bouchaert I, AdibConquy M, Cavaillon JM, Pinsky MR, Dhainaut JF, Polla BS: Mitochondrial membrane potential and apoptosis peripheral blood monocytes in severe human sepsis. Am J Respir Crit Care Med 2001, 164:389-395

76. Brealey D, Brand M, Hargreaves I, Heales S, Land J, Smolenski R, Davies NA Cooper CE, Singer M: Association between mitochondrial dysfunction and severity and outcome of septic shock. Lancet 2002, 360:219-223.

77. Belikova I, Lukaszewicz AC, Faivre V, Damoisel C, Singer M, Payen D: Oxygen consumption of human peripheral blood mononuclear cells in severe human sepsis. Crit Care Med 2007, 35:2702-2708.

78. Crouser ED, Julian MW, Huff JE, Joshi MS, Bauer JA, Gadd ME, Wewers MD, Pfeiffer DR: Abnormal permeability of inner and outer mitochondrial membranes contributes independently to mitochondrial dysfunction in the liver during acute endotoxemia. Crit Care Med 2004, 32:478-488.

79. Singer M: Metabolic failure. Crit Care Med 2005, 33(12 Suppl):S539-542.

80. Mehta VK, Hao W, Brooks-Worrell BM, Palmer JP: Low-dose interleukin 1 and tumor necrosis factor individually stimulate insulin release but in combination cause suppression. Eur J Endocrino/ 1994, 130:208-214.

81. Marik PE, Raghavan M: Stress-hyperglycemia, insulin and immunomodulation in sepsis. Intensive Care Med 2004, 30:748-756.

82. Chambrier C, Laville M, Rhzioual Berrada K, Odeon M, Bouletreau P, Beylot M: Insulin sensitivity of glucose and fat metabolism in severe sepsis. Clin Sci (Lond) 2000, 99:321-328.

83. Deutschman CS, De Maio A, Clemens MG: Sepsis-induced attenuation of glucagon and 8-BrcAMP modulation of the phosphoenolpyruvate 
carboxykinase gene. Am J Physiol 1995, 269:R584-591

84. Deutschman CS, Andrejko KM, Haber BA, Bellin L, Elenko E, Harrison R, Taub R: Sepsis-induced depression of rat glucose-6-phosphatase gene expression and activity. Am J Physiol 1997, 273:R1709-1718.

85. Thompson LH, Kim HT, Ma Y, Kokorina NA, Messina JL: Acute, muscle-type specific insulin resistance following injury. Mol Med 2008, 14:715-723.

86. Petit F, Bagby GJ, Lang CH: Tumor necrosis factor mediates zymosaninduced increase in glucose flux and insulin resistance. Am J Physiol 1995, 268:E219-228.

87. Abordo EA, Westwood ME, Thornalley PJ: Synthesis and secretion of macrophage colony stimulating factor by mature human monocytes and human monocytic THP-1 cells induced by human serum albumin derivatives modified with methylglyoxal and glucose-derived advanced glycation endproducts. Immunol Lett 1996, 53:7-13.

88. McCowen KC, Ling PR, Ciccarone A, Mao Y, Chow JC, Bistrian BR, Smith RJ: Sustained endotoxemia leads to marked down-regulation of early steps in the insulin-signaling cascade. Crit Care Med 2001, 29:839-846.

89. Ma Y, Toth B, Keeton AB, Holland LT, Chaudry IH, Messina JL: Mechanisms of hemorrhage-induced hepatic insulin resistance: role of tumor necrosis factor-alpha. Endocrinology 2004, 145:5168-5176.

90. Van den Berghe G: How does blood glucose control with insulin save lives in intensive care? J Clin Invest 2004, 114:1187-1195.

91. Savage DB, Petersen KF, Shulman GI: Mechanisms of insulin resistance in humans and possible links with inflammation. Hypertension 2005, 45:828-833

92. Ghanim H, Aljada A, Daoud N, Deopurkar R, Chaudhuri A, Dandona P: Role of inflammatory mediators in the suppression of insulin receptor phosphorylation in circulating mononuclear cells of obese subjects. Diabetologia 2007, 50:278-285.

93. Leng L, Metz CN, Fang Y, Xu J, Donnelly S, Baugh J, Delohery T, Chen Y, Mitchell RA, Bucala R: MIF signal transduction initiated by binding to CD74. JExp Med 2003, 197:1467-1476.

94. Waeber G, Calandra T, Roduit R, Haefliger JA, Bonny C, Thompson N, Thorens B, Temler E, Meinhardt A, Bacher M, Metz CN, Nicod P, Bucala R: Insulin secretion is regulated by the glucose-dependent production of islet beta cell macrophage migration inhibitory factor. Proc Natl Acad Sci U S A 1997, 94:4782-4787.

95. Benigni F, Atsumi T, Calandra T, Metz C, Echtenacher B, Peng T, Bucala R: The proinflammatory mediator macrophage migration inhibitory factor induces glucose catabolism in muscle. J Clin Invest 2000, 106:1291-1300.

96. Atsumi T, Cho YR, Leng L, McDonald C, Yu T, Danton C, Hong EG, Mitchell RA, Metz C, Niwa H, Takeuchi J, Onodera S, Umino T, Yoshioka N, Koike T, Kim JK, Bucala R: The proinflammatory cytokine macrophage migration inhibitory factor regulates glucose metabolism during systemic inflammation. J Immunol 2007, 179:5399-5406

97. Lambillotte C, Gilon P, Henquin JC: Direct glucocorticoid inhibition of insulin secretion. An in vitro study of dexamethasone effects in mouse islets. J Clin Invest 1997, 99:414-423.

98. Hargrove DM, Bagby GJ, Lang CH, Spitzer JJ: Adrenergic blockade prevents endotoxin-induced increases in glucose metabolism. Am J Physiol 1988, 255:E629-635

99. Ottlakan A, Spolarics Z, Lang CH, Spitzer JJ: Adrenergic blockade attenuates endotoxin-induced hepatic glucose uptake. Circ Shock 1993, 39:74-79.

100. Hargrove DM, Lang CH, Bagby GJ, Spitzer JJ: Epinephrine-induced increase in glucose turnover is diminished during sepsis. Metabolism 1989 38:1070-1076

101. McGuinness OP, Jacobs J, Moran C, Lacy B: Impact of infection on hepatic disposal of a peripheral glucose infusion in the conscious dog. Am J Physiol 1995, 269:E199-207.

102. Losser MR, Bernard C, Beaudeux JL, Pison C, Payen D: Glucose modulates hemodynamic, metabolic, and inflammatory responses to lipopolysaccharide in rabbits. J Appl Physiol 1997, 83:1566-1574.

103. Screaton RA, Conkright MD, Katoh Y, Best JL, Canettieri G, Jeffries S, Guzman E, Niessen S, Yates JR, 3rd, Takemori H, Okamoto M, Montminy M: The CREB coactivator TORC2 functions as a calcium- and CAMP-sensitive coincidence detector. Cell 2004, 119:61-74.

104. Koo SH, Flechner L, Qi L, Zhang X, Screaton RA, Jeffries S, Hedrick S, Xu W, Boussouar F, Brindle P, Takemori H, Montminy M: The CREB coactivator TORC2 is a key regulator of fasting glucose metabolism. Nature 2005, 437:1109-1111.

105. Birnbaum MJ: Signal transduction. Sweet conundrum. Science 2008 ,
319:1348-1349.

106. Brownlee M: Biochemistry and molecular cell biology of diabetic complications. Nature 2001, 414:813-820.

107. Dentin R, Hedrick S, Xie J, Yates J 3rd, Montminy M: Hepatic glucose sensing via the CREB coactivator CRTC2. Science 2008, 319:1402-1405.

108. Brownlee M: The pathobiology of diabetic complications: a unifying mechanism. Diabetes 2005, 54:1615-1625.

109. Korshunov SS, Skulachev VP, Starkov AA: High protonic potential actuates a mechanism of production of reactive oxygen species in mitochondria. FEBS Lett 1997, 416:15-18.

110. Nishikawa T, Edelstein D, Du XL, Yamagishi S, Matsumura T, Kaneda Y, Yorek MA, Beebe D, Oates PJ, Hammes HP, Giardino I, Brownlee M: Normalizing mitochondrial superoxide production blocks three pathways of hyperglycaemic damage. Nature 2000, 404:787-790

111. Du X, Matsumura T, Edelstein D, Rossetti L, Zsengeller Z, Szabo C, Brownlee M: Inhibition of GAPDH activity by poly(ADP-ribose) polymerase activates three major pathways of hyperglycemic damage in endothelial cells. $J$ Clin Invest 2003, 112:1049-1057.

112. Dandona P, Mohanty P, Chaudhuri A, Garg R, Aljada A: Insulin infusion in acute illness. J Clin Invest 2005, 115:2069-2072.

113. Dhindsa S, Tripathy D, Mohanty P, Ghanim H, Syed T, Aljada A, Dandona P: Differential effects of glucose and alcohol on reactive oxygen species generation and intranuclear nuclear factor-kappaB in mononuclear cells. Metabolism 2004, 53:330-334.

114. Aljada A, Friedman J, Ghanim H, Mohanty P, Hofmeyer D, Chaudhuri A, Dandona P: Glucose ingestion induces an increase in intranuclear nuclear factor kappaB, a fall in cellular inhibitor kappaB, and an increase in tumor necrosis factor alpha messenger RNA by mononuclear cells in healthy human subjects. Metabolism 2006, 55:1177-1185.

115. Aljada A, Ghanim H, Mohanty P, Syed T, Bandyopadhyay A, Dandona P: Glucose intake induces an increase in activator protein 1 and early growth response 1 binding activities, in the expression of tissue factor and matrix metalloproteinase in mononuclear cells, and in plasma tissue factor and matrix metalloproteinase concentrations. Am J Clin Nutr 2004, 80:51-57.

116. Ceriello A, Quagliaro L, Piconi L, Assaloni R, Da Ros R, Maier A, Esposito K, Giugliano D: Effect of postprandial hypertriglyceridemia and hyperglycemia on circulating adhesion molecules and oxidative stress generation and the possible role of simvastatin treatment. Diabetes 2004, 53:701-710.

117. Esposito K, Nappo F, Marfella R, Giugliano G, Giugliano F, Ciotola M, Quagliaro L, Ceriello A, Giugliano D: Inflammatory cytokine concentrations are acutely increased by hyperglycemia in humans: role of oxidative stress. Circulation 2002, 106:2067-2072

118. Orlinska U, Newton RC: Role of glucose in interleukin-1 beta production by lipopolysaccharide-activated human monocytes. J Cell Physiol 1993, 157:201-208.

119. Payen DM, Fratacci MD, Dupuy P, Gatecel C, Vigouroux C, Ozier Y, Houssin D, Chapuis Y: Portal and hepatic arterial blood flow measurements of human transplanted liver by implanted Doppler probes: interest for early complications and nutrition. Surgery 1990, 107:417-427.

120. Korkmaz CG, Korkmaz KS, Kurys P, Elbi C, Wang L, Klokk TI, Hammarstrom C, Troen G, Svindland A, Hager GL, Saatcioglu F: Molecular cloning and characterization of STAMP2, an androgen-regulated six transmembrane protein that is overexpressed in prostate cancer. Oncogene 2005, 24:4934-4945.

121. Wellen KE, Fucho R, Gregor MF, Furuhashi M, Morgan C, Lindstad T, Vaillancourt E, Gorgun CZ, Saatcioglu F, Hotamisligil GS: Coordinated regulation of nutrient and inflammatory responses by STAMP2 is essential for metabolic homeostasis. Cell 2007, 129:537-548.

122. Mohanty P, Hamouda W, Garg R, Aljada A, Ghanim H, Dandona P: Glucose challenge stimulates reactive oxygen species (ROS) generation by leucocytes. J Clin Endocrinol Metab 2000, 85:2970-2973.

123. Damoisel C, Belikova I, Faivre V, Losser MR, Payen D: Hyperglycemia alters human peripheral blood mononuclear cells oxygen consumption in control and septic conditions [Abstract]. Intensive Care Med 2007, 33(S2):S119.

124. Leverve X: Hyperglycemia and oxidative stress: complex relationships with attractive prospects. Intensive Care Med 2003, 29:511-514.

125. Suh SW, Gum ET, Hamby AM, Chan PH, Swanson RA: Hypoglycemic neuronal death is triggered by glucose reperfusion and activation of neuronal NADPH oxidase. J Clin Invest 2007, 117:910-918. 
126. Ali NA, O'Brien JM Jr, Dungan K, Phillips G, Marsh CB, Lemeshow S, Connors AF Jr, Preiser JC: Glucose variability and mortality in patients with sepsis. Crit Care Med 2008, 36:2316-2321.

127. Hermanides J, Vriesendorp TM, Bosman RJ, Zandstra DF, Hoekstra JB, Devries $\mathrm{JH}$ : Glucose variability is associated with intensive care unit mortality. Crit Care Med 2010, 38:838-842.

128. Deane AM, Chapman MJ, Fraser RJ, Burgstad CM, Besanko LK, Horowitz M: The effect of exogenous glucagon-like peptide- 1 on the glycaemic response to small intestinal nutrient in the critically ill: a randomised double-blind placebo-controlled cross over study. Crit Care 2009, 13:R67.

129. Marik PE, Pinsky M: Death by parenteral nutrition. Intensive Care Med 2003, 29:867-869.
130. Marik PE: Death by total parenteral nutrition: part deaux. Crit Care Med 2006, 34:3062; author reply 3062-3063.

131. Hippocrates: The Aphorisms of Hippocrates. New York: The Classics of Medicine Library; 1982.

doi:10.1186/cc9100

Cite this article as: Losser M-R, et al:: Glucose and stress conditions in the intensive care unit. Critical Care 2010, 14:231. 